\title{
IMPLEMENTATION OF TEACHER AND PEER FEEDBACK IN WRITING HORTATORY EXPOSITION TEXT
}

\author{
Putri Lasminiar \\ English Department, Faculty of Letters, Universitas Negeri Malang, Malang 65145, Indonesia \\ (lasminiarputri@gmail.com)
}

\begin{abstract}
Feedback from teacher and peer is doubted by experts to be implemented in the students' writing process because of students' preference in teacher feedback and students' lack of ability to give feedback. Therefore, the purpose of this study was to investigate the implementation of teacher and peer feedback in the eleventh graders of SMAN 5 Malang in writing hortatory exposition texts. It is Collaborative Classroom Action Research (CAR) and the data were obtained through questionnaires, interview guides, observation checklist, field notes, and students' writing assignments. The results showed that the implementation of teacher and peer feedback improved the students' ability in writing hortatory exposition texts especially in the relating thesis statement, argument(s), and recommendation into one another. In terms of content, organization, language use, and mechanic, there were more than $75 \%$ of 32 students that could reach score at least 3 (the minimum score). The result also revealed that teacher and peer feedback could create students to become critical and independent learners.
\end{abstract}

Keywords: Hortatory Exposition Text; Teacher and Peer Feedback; Writing

First Received:

Final Proof Received:

(June 31, 2020)

(September 21, 2020)

\section{INTRODUCTION}

Writing is a process of continuing discovery about what the writers want to put in their writing. They usually explore their thoughts so that they finally find out the best statements which are appropriate with the topic they have (Langan, 2001). On the other hand, Saville-Troike (2006) have an opinion that writing is a productive activity for L2 learners where they can learn how to communicate with their readers properly. From those statements, it can be concluded that writing is a productive skill for L2 learners where they can learn about relating ideas or thoughts with the topic they have so that the reader can understand the mean of their writing.

As a matter of fact, sometimes the writers face some difficulties in stating their thoughts or feelings through written language. Those difficulties are also faced by the eleventh graders of SMAN 5 Malang when they are assigned to write a certain English essay, especially in writing a hortatory exposition. Based on the preliminary study, the students could not relate the thesis statement, argument(s), and recommendation as to the generic structure of the text. Furthermore, they could not organize the ideas into a correct generic structure and put the language features of the text in their writing so their writing became ungrammatical. The ungrammatical texts sometimes made the readers unable to 
get the thoughts or feelings which put in the students' essays. In doing writing assignments, the students also did not seem enthusiastic and they considered that writing activity as a boring activity. To overcome the problems, the students need feedback that can assist them to write well-covering content, organization, language use, and mechanics.

Hill (2007) identifies the important role of feedback in the learning cycle. The cycle is similar to plan, do, reflect, and act. In terms of the writing process, feedback is a crucial aspect of any writing instruction (Rodliyah, Cahyono, Widiati, \& Prayogo, 2017). Chaudron (1988) elaborates feedback from teacher's and learner's perspectives. He believes that perspectives from teacher and learner can help students improve their performance, especially in writing activities since it gives information about what is correct or incorrect in their performance. In line with Chaudron's statement, a study conducted by Lestari (2008) also reveals that feedback given by teachers and peers can influence the input that the learners receive since the more interactions between student-student and studentteacher occur, the more input the learners receive.

In previous studies, some researchers reveal different research findings related to teacher and peer feedback. Carnell (2000) and Sheen, et. al. (2009) believe that teacher feedback can help students in their revision process since the feedback provides critics and bits of advice. Yet, Xiao \& Lucking (2008) argue that the implementation of teacher feedback could not enhance students' writing. Meanwhile, in terms of peer feedback, it is beneficial for the construction of the writing process (Yang, et al, 2006). However, Choi (2013) states that students do not consider themselves qualified to provide useful feedback, partly due to their lack of language ability.

Concerning the studies above, it can be concluded that teacher feedback and peer feedback have their strengths and weaknesses. However, the point is the teacher and peer feedback can assist students to make their performance better in writing. Because of the reason, this study wants to combine the two feedback to be a guide for students to make their writing-related each other and readers can understand the meaning that they put in each paragraph. The two feedback is needed by the students because they are able to give comments on various aspects of writing, from content to grammar (Park, 2017). It is also supported by a research study conducted by Tai, Lin, \& Yang (2015). The research finding reveals that students in the teacher feedback and peer feedback group demonstrate greater improvements than those who receive only teacher feedback in terms of holistic writing skills and subscales of content, organization, grammar, mechanics, and style.

Since there are many advantages produced by the teacher and peer feedback in writing skills, this study aims to investigate the implementation of teacher and peer feedback in students' hortatory exposition texts. In general, this research has one major question, how the implementation of teacher and peer feedback can improve the students' ability in terms of content, organization, language use, and mechanics and also students' attention in writing hortatory exposition texts of the eleventh graders of SMAN 5 Malang. 


\section{LITERATURE REVIEW}

\section{Teacher Feedback}

Teacher feedback is teachers' information which can be advice and correction given to the learners and those can help them to access knowledge and incorporate that knowledge into their written work so the ideas therein are developed to the extent expected in academic writing Soles (2007). In line with that, besides advice and correction, teacher feedback clarifies goals, gives a sense of direction, identifies mistakes, and provides bits of advice. According to Rodliyah et al., (2017), students were motivated to read their teacher feedback. Moreover, Widiastuti, et. al., (2019) stated that feedback given by the teachers help them improve their presentation. However, in a Teacher Feedback situation, students do not feel free to write because they are conscious of the fact that they will be read and corrected by the teacher Rachmayani, Rifai, \& Rohadi, (2018). On the other hand, White et al. (1997, cited in Dean, et. al, 2011) believe that teachers should provide students with feedback when they are first learning how to set the learning objectives. It is also supported by a research study done by (Tai et al., 2015). He believes that teachers could identify students' errors accurately, supply alternative means of expression, and identify weaknesses in content.

\section{Peer Feedback}

Another feedback that can be used to enhance students' writing ability is peer feedback. Peer feedback is an ongoing process in which peers provide and communicate information to students in order to help them confirm, refine, or restructure various kinds of knowledge, strategies, and beliefs that are related to the learning objectives Hattie \& Timperley (2007). It is also supported by a research finding done by Burgess and Head (2005). They convey that peer feedback encourages constructive interaction between class members and will help them think more critically about their own work. In line with that, Cahyono and Widiati (2015) also state that through peer feedback activity, students can learn and practice how to read and respond to others' writing, how to communicate their perceptions of the text they have read to the writer, and how to revise their own text based on the comments from peers for a better quality writing. However, Saito and Fujita (2004) have reported that peer reviewers have limited knowledge, experience, and language ability.

Furthermore, Carson and Nelson, 1996; Harmer, 2004; Mangelsdorf, 1992; Park, 2017, and Min, 2005) also believe that the main reasons for unsuccessful peer review are misunderstanding the writer's intentions and receiving ambiguous feedback. Yet, some researchers convince the importance of providing training on being a good reviewer to raise the quality of peer reviews (e.g., Berg, 1999; Hansen \& Liu, 2005; Lam, 2010). In Min (2006), peer review training does not only increase comments incorporated in the subsequent draft but also enhance the quality of students' revisions. Besides enhancing 
the quality of students' revision, peer feedback also motivate them to write better when they found their writing mistakes because they positively thought that the mistakes were a normal thing for learners (Rachmayani et al., 2018). Biri (2014) also points out that peer feedback improves self-confidence and motivation for lessons.

\section{METHOD}

Collaborative Classroom Action Research (CAR) was used as a research design where the researcher acted as the observer and the classroom English teacher conducted teaching and learning activities. The researcher used this research design because she wanted to assist the teacher to interpret the research implementation made by the researcher. It is in line with Lodico, Spaulding, \& Voegtle (2006) who believes that collaborators can help classroom teacher in the reflections, data collection, and data analysis. This research employed two cycles since in the first cycle the research could not meet the criteria of success, which is at least $75 \%$ of students can reach a score at least 3 in terms of content, organization, language use, and mechanics. The subjects of this study were 32 eleventh graders of IPS 1 of SMAN 5 Malang. To get the data from the subjects, the instruments used are questionnaires, interview guides, observation checklists, filed notes, and students' writing assignments. In delivering teacher and peer feedback, the researcher used teacher and peer feedback checklists because it was easier and used as a guideline by students to make their writing coherent and organized.

This study was implemented in two cycles and each cycle consisted of three meetings. Each meeting lasted for 90 minutes. Some steps of composing the essay namely pre-writing, drafting, and post writing are applied in each cycle. First, the pre-writing activity dealt with asking students to make an outline in order to help them organize their ideas of their writing into the correct order. Second, drafting activity focused on allowing the students to write individually based on the outline they made. And the third is postwriting included three activities; revising, editing, and publishing.

First is revising activity, the teacher and the peer have an opportunity to give feedback on the students' writing by using the checklist. There was a difference between revising in cycle 1 and cycle 2 . In cycle 1 , the students swapped their drafts with their friend who sat next to them to be given peer feedback as they finished their drafts while in cycle 2, they swapped their drafts with their friend who sat behind them to be given peer feedback as they finished their drafts to avoid students' boredom and to get different feedback from a different peer. Second is editing activity, the students edited their writing assignment based on the feedback. After that, they wrote their final compositions and then submitted them to the teacher. And the last is a publishing activity where the teacher asked some of the students to read their final composition in front of the class. 


\section{RESULTS AND DISCUSSION}

\section{Results}

The findings of the action research were obtained from the result of questionnaires, interview guide, observation checklist, field notes, and students' writing assignments. To know the improvement of the students' ability in writing hortatory exposition texts, the mean scores of students' writing in terms of content, organization, language use, and mechanics were computed. The mean score of students' writing in terms of content improved from 2.66 in the preliminary study to 2.95 in Cycle 1 and it did not meet the criteria of success. On the other hand, the mean score of students' writing in Cycle 2 got better. They achieve 3.56 and this result was above the criteria of success of this research.

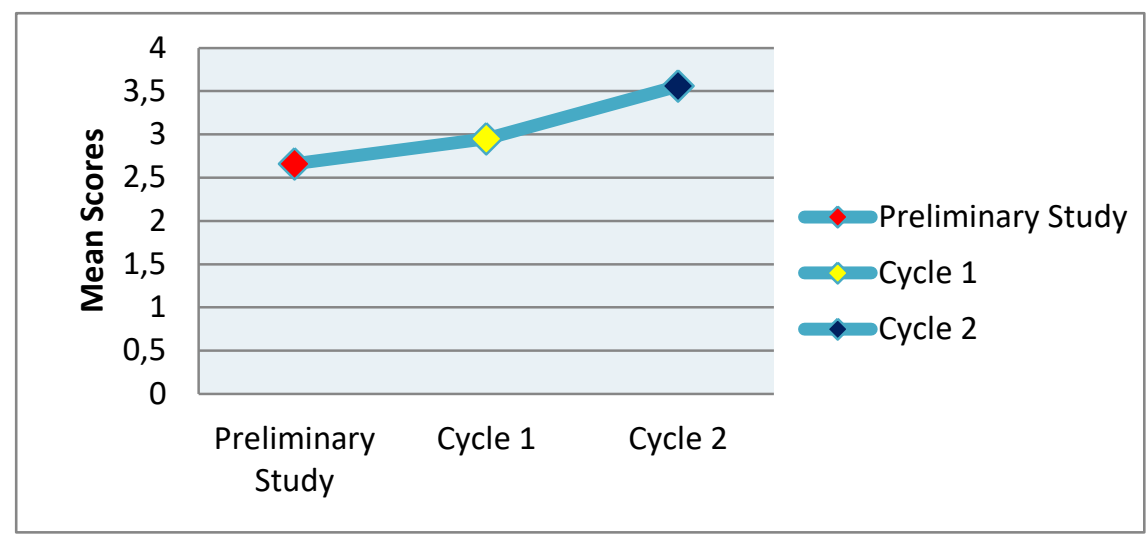

Fig. 1. The Mean Scores of Students' Writing in terms of Content in Preliminary Study, Cycle 1, and Cycle 2

The mean score of students' writing in terms of organization improved from 2.875 in the preliminary study to 3.22 in Cycle 1 and it had met the criteria of success. When the researcher continued the research to the next cycle, the students' mean score increased as it could reach 3.58 in terms of organization.

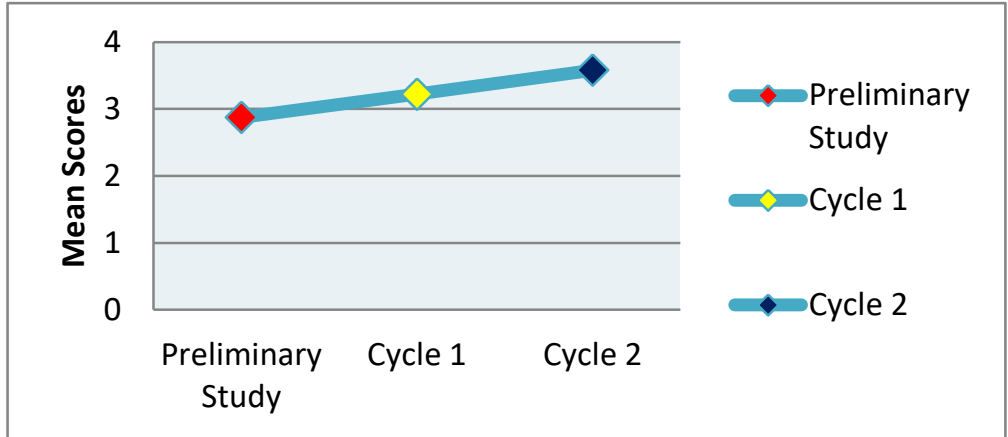

Fig. 2. The Mean Scores of Students' Writing in terms of Organization in Preliminary Study, Cycle 1, and Cycle 2

The mean score of students' writing in terms of language use improved from 2.78 in the preliminary study to 3.14 in Cycle 1 and it had met the criteria of success. When the 
researcher continued the research to the next cycle, the students' mean score increased as it could reach 3.48 in terms of language use.

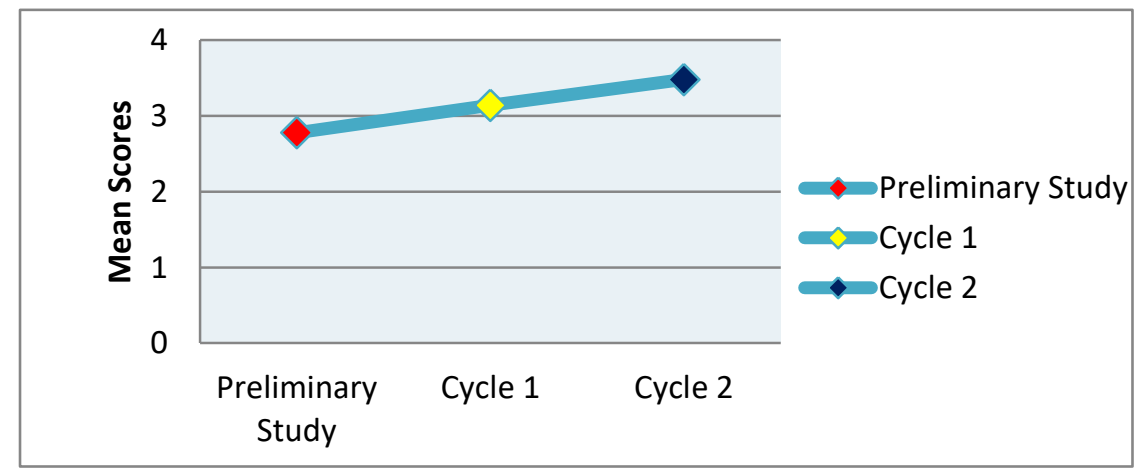

Fig. 3. The Mean Scores of Students' Writing in terms of Language Use in Preliminary Study, Cycle 1, and Cycle 2

The mean score of students' writing improved from 2.86 in the preliminary study to 3.125 in Cycle 1 and it had met the criteria of success. When the researcher continued the research to the next cycle, the students' mean score increased as it could reach 3.59 in terms of mechanics. It means that the students' mean scores in Cycle 2 had better improvement than in the preliminary study and Cycle 1 .

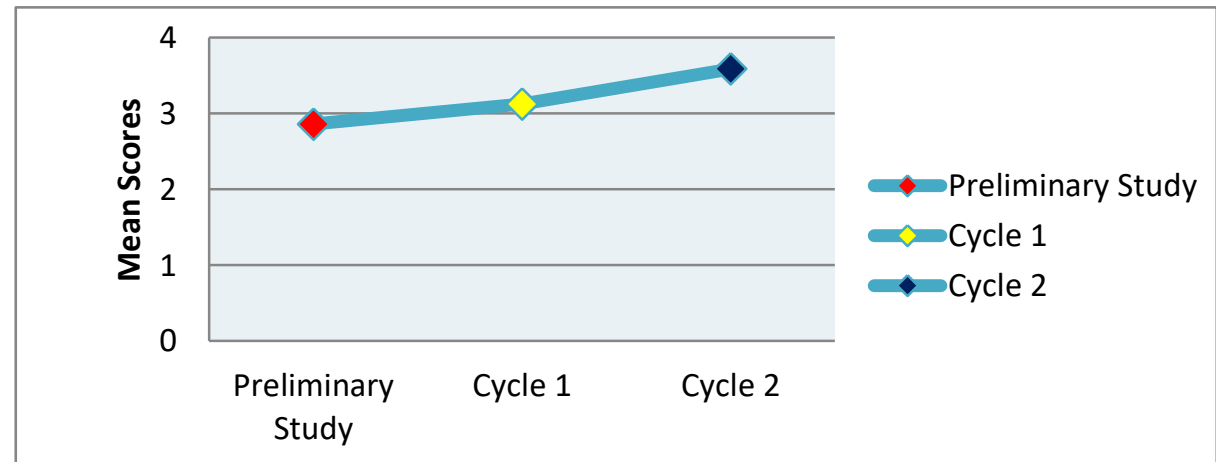

Fig. 4. The Mean Scores of Students' Writing in terms of Mechanics in Preliminary Study, Cycle 1, and Cycle 2

From the analysis in cycle 2, it was found that the results of the students' writing were getting improved cycle 1 to cycle 2 and the results also had met the criteria of success. There were more than $75 \%$ of the students who achieved the score above the minimum standard of passing score in terms of content, organization, language use, and mechanics although the rest of them still made some mistakes. For example, there were fewer mistakes in language use, especially in the use of modals and conjunctions and to minimize the students' problem, the teacher gave handouts and exercises. In terms of mechanics, there were also fewer mistakes in punctuation, spelling, capitalization, and paragraphing. To overcome the problem, the teacher and the student made a discussion about how to make students' paragraphs related to one another by reading the two topics of hortatory exposition text. By doing the activity, the students can learn the right English 
spelling and capitalization from the text and apply them in their essays. For the punctuation problem, the teacher gave handouts about conjunction along with the punctuation as a guideline for the students' essay. Therefore, since both criteria of success either in terms of process or the product had been achieved in cycle 2, this study stopped the process of implementing teacher and peer feedback to the students in the cycle.

The result of the observation checklist and field notes showed that the students' attention in the teaching and learning of writing got better from the preliminary study to cycle 1 and from cycle 1 to cycle 2 . More than $75 \%$ of the students participated in the teaching and learning of writing such as doing exercises and asking and answering about the lessons related to language features of hortatory exposition text.

Meanwhile, the result of the students' questionnaire about their responses to the application of teacher and peer feedback can be described as follows. Responding to the first question about whether or not the implementation of teacher and peer feedback influenced students' confidence in writing hortatory exposition text, there were 5 students (16\%) out of 32 students who felt confident, 24 students $(75 \%)$ who felt that their confidence had improved, 2 students (6.25\%) said that their confidence was increased a little, and 1 student (3.125\%) who were not confident in writing hortatory exposition text. In brief, the application of teacher and peer feedback in the writing process had increased students' confidence.

In the second question about whether or not the implementation of teacher feedback in the writing process helped students particularly in making students' paragraph coherent to one another, it was found out that 15 students (46.875\%) stated that it helped them very much, 16 students (50\%) stated that it helped them and 1 student $(3.125 \%)$ stated that it helped the student a little.

In the third question about whether or not the implementation of peer feedback in the writing process helped students particularly in making students' paragraph coherent to one another, it was found out that 13 students (40.625\%) stated that it helped them very much, 17 students (53.125\%) stated that it helped them and 2 students (6.25\%) stated that it helped them a little.

Responding to the fourth question about students' motivation after getting teacher feedback in their writing, it was found out that 14 students $(43.75 \%)$ stated that the students were greatly motivated to revise their writing after getting teacher feedback, 17 students (53.125\%) were motivated and there was only 1 student $(3.125 \%)$ who was motivated a little bit to revise his/her writing after getting teacher feedback.

Responding to the fifth question about students' motivation after getting peer feedback in their writing, it was found out that 12 students (37.5\%) stated that the students were greatly motivated to revise their writing after getting peer feedback, 18 students (56.25\%) were motivated and there were only 2 students $(6.25 \%)$ who were motivated a little bit to revise their writing after getting peer feedback. 
In the sixth question about students' opinions related to the importance of the use of teacher and peer feedback in the writing process to be developed and applied in the next writing activities, there were 14 students (43.75\%) stating that it was very important. 17 students $(53.125 \%)$ considered that it was important enough and there was only 1 student (3.125\%) considering that it was a little bit important. Indeed, no students considered that it was not important to develop or apply teacher and peer feedback in the writing process for the next writing activities.

Related to the result of the interview with the classroom English teacher about her responses to the application of teacher and peer feedback, she said that the implementation of the two feedbacks was really useful to help students in connecting paragraphs to become a coherent and organized hortatory exposition essay.

Regarding the things that might need some improvements in applying the teacher and peer feedback, she said that there were some words stated in teacher and peer feedback checklists that made students unable to comprehend and the timing of the generic structures of hortatory exposition's explanation that the researcher stated in the lesson plans was not enough to make students understand about it. However, she said that those weaknesses had already been mended in Cycle 2. Because of some improvements done by the researcher in Cycle 2, the students understood the methods better and became more independent in doing the methods. In the interview, the teacher also said that students' participation in the teaching and learning activities was quite good that reflected that the application of teacher and peer feedback did not burden them. Moreover, related to the students' attention in the teacher's explanation about language features of hortatory exposition text and the other learning materials was good. The feedback also could make students critical in comprehending suggestions or directions that could come from a teacher or peer and it could help them make their writing better. She also considered that teacher and peer feedback were not difficult to be applied in other classes and different English text types because the procedures were understandable.

\section{DISCUSSIONS}

The present study showed that implementing feedback in the teaching and learning of writing had helped students in producing hortatory exposition texts. Through feedback, the students could also get inputs and knowledge that made them be better learners. It is in line with the statement stated by Dean et al., (2011) which says that feedback can be helpful for the students since it gives suggestions and information to the students that can help them improve their performance and solidify their understanding of learning objective. Learning objectives in the researcher's research study meant that the students should understand and apply the generic structures, social function, and language features of hortatory exposition text in their essays. 
In this study, the teacher used the teacher feedback checklist to provide guidance such as putting the advice and a certain pattern or formula for an English lesson. Besides the checklist, the teacher made circles on the students' mistakes in their writing. In other words, the teacher did not help the students by giving the right answer for their mistake in their writing directly but they should think by themselves to correct the mistake. The activity is supported by a research study done by Carnell (2000) which says that teacher feedback clarifies goals, gives a sense of direction, identifies mistakes, and provides bits of advice. The activity also can encourage the students to search for answers actively instead of being fed by the teacher's knowledge Tai et al., (2015). Thus, the feedback given by the teacher could create the students to become more independent in the learning activities because the feedback asked them to learn by themselves on how they comprehend the feedback in their works.

Besides getting assistance from teacher feedback, the students could also get assistance from peer feedback to help them correct their mistakes of their writing. By implementing peer feedback, the students become critical learners for themselves and teachers for their friends. Moreover, they could also share their knowledge they had by giving suggestions or comments to help their classmates' writing get better especially in relating the generic structures of a hortatory exposition text into one another. In line with that, a study conducted by Ting \& Qian (2010) also say that peer feedback will make students become more critical readers and revisers through reading others' writing critically. In line with the statement, a research study conducted by (Kusumaningrum, Cahyono, \& Prayogo (2019) stated that responding to peer's writing can build the critical skills that are needed to analyze and revise one's own writing. This statement is supported by B. Y. Cahyono and Widiati (2004) which reveals that students become more critical learners and teachers because through peer feedback activity students can learn and practice how to read and respond to others' writing, how to communicate their perceptions of the text they have read to the writer, and how to revise their own text based on the comments from peers for a better quality of their writing.

The results of the study show that the implementation of teacher and peer feedback has many advantages for the students. Besides creating the students to be critical and independent learners, the feedback had also increased the students' attention in the process of writing hortatory exposition essays since they would feel challenged or encouraged when their teacher or their peer always corrected the mistakes they made in their writing task (Hartono, 2008, cited in Cahyono, 2010).

\section{CONCLUSION}

The implementation of teacher and peer feedback is effective to help the students in writing hortatory exposition essays, especially in the relating thesis statement, argument(s), and recommendation into one another. Moreover, the feedback given by the 
teacher and peer is also helpful to combine their sentences into coherent paragraphs. Teacher and peer feedback is effective and helpful because the feedback placed in the checklists could assist students to know their mistakes they made in their writing. As they knew their mistakes, they tried to correct it by reviewing the lessons which had been explained by the teacher. Besides, by reading the model of hortatory exposition texts, the students can learn and comprehend the correct structure and content of the texts in order to make their writing get improved. It also helps the students to relate the generic structures of the text into one another and combine the sentences into coherent paragraphs. It has improved students' scores in writing hortatory exposition essays in terms of content, organization, language use, and mechanics. Moreover, it also increased the students' attention in the process of writing hortatory exposition essays. Furthermore, the implementation of teacher and peer feedback creates the students to become more critical and independent in the teaching and learning of writing.

\section{REFERENCES}

Berg, E. C. (1999). The Effects of Trained Peer Response on ESL Students' Revision Types a Writing Quality. Journal of Second Language Writing, 8(3), 215-241. doi: 10.1016/S1060-3743(99)80115-5.

Burgess, S., \& Head, K. (2005). How to Teach for Exams. London: Longman.

Cahyono, B. Y. (2010). Second Language Acquisition and English Language Teaching. Malang: State University of Malang Press.

Cahyono, B. Y., \& Widiati, U. (2004). The Tapestry of English Language Teaching and Learning in Indonesia. Malang: State University of Malang Press.

Cahyono, B. Y., \& Widiati, U. (2015). The Teaching of EFL Listening in the Indonesian Context: The State of the Art. TEFLIN Journal, 20(2), 194-211. doi: 10.15639/teflinjournal.v20i2/194-211.

Carnell, E. (2000). Dialogue, Discussion and Secondary School Students on How Others Help Their Learning (Askew, Ed.). London: Routledge.

Carson, J. G., \& Nelson, G. L. (1996). Chinese Students' Perceptions of ESL Peer Response Group Interaction. Journal of Second Language Writing, 5(1), 1-19. doi: 10.1016/S1060-3743(96)90012-0.

Chaudron, C. (1988). Second Language Classroom Research on Teaching and Learning. Cambridge: Cambridge University Press.

Choi, J. (2013). Does Peer Feedback Affect L2 Writers' L2 Learning, Composition Skills, Metacognitive Knowledge, and L2 Writing Anxiety. English Teaching, 68(3), 187213. doi: 10.15858/ENGTEA.68.3.201309.187.

Dean, C. B., Hubbell, E. R., Pitler, H., \& Stone, B. J. (2011). Classroom Instruction that Works: Research-based Strategies for Increasing Student Achievement (2nd ed.). Colorado: McREL.

H., B. (2014). Contribution of Peer Assessment Method to Teacher Education (Unpublished Master Thesis). Karadeniz Technical University Institute of Educational Sciences, Trabzon. 
Hansen, J. G., \& Liu, J. (2005). Guiding Principles for Effective Peer Response. ELT Journal, 59(1), 31-38. doi: 10.1093/elt/cci004.

Harmer, J. (2004). The Practice of English Language Teaching. New York: Pearson Longman.

Hattie, J., \& Timperley, H. (2007). The Power of Feedback. Review of Educational Research, 77(1), 81-112. doi: 10.3102/003465430298487.

Hill, F. (2007). Feedback to Enhance Student Learning: Facilitating Interactive Feedback on Clinical Skills. International Journal of Clinical Skill, 1(1), 21-24.

Kusumaningrum, S. R., Cahyono, B. Y., \& Prayogo, J. A. (2019). The Effect of Different Types of Peer Feedback Provision on EFL Students' Writing Performance. International Journal of Instruction, 12(1), 213-224. doi: 10.29333/iji.2019.12114app.213-224.

Lam, R. (2010). A Peer Review Training Workshop: Coaching Students to Give and Evaluate Peer Feedback. TESL Canada Journal, 27(2), 114. doi: 10.18806/tesl.v27i2.1052.

Langan, J. (2001). College Writing Skills with Readings. New York: McGraw-Hill Ryerson, Limited.

Lestari, L. A. (2008). The Interactional Approach to the Teaching of Writing and its Implications for Second Language Acquisition. TEFLIN Journal, 19(1), 42-56. doi: 10.15639/teflinjournal.v19i1/42-56.

Lodico, M. G., Spaulding, D. T., \& Voegtle, K. H. (2006). Methods in Educational Research: From Theory to Practice. San Fransisco: John Wiley \& Sons.

Mangelsdorf, K. (1992). Peer Reviews in the ESL Composition Classroom: What do the Students Think? ELT Journal, 46(3), 274-284. doi: 10.1093/elt/46.3.274.

Min, H.-T. (2005). Training Students to Become Successful Peer Reviewers. System, 33(2), 293-308. doi: 10.1016/j.system.2004.11.003.

Min, H.-T. (2006). The Effects of Trained Peer Review on EFL Students' Revision Types and Writing Quality. Journal of Second Language Writing, 15(2), 118-141. doi: 10.1016/j.jslw.2006.01.003.

Park, J. (2017). Benefits of the Process Approach in L2 Writing: From the Prospective Teachers' Perspectives. The Journal of Linguistics Science, 82, 117-136. doi: 10.21296/jls.2017.09.82.117.

Rachmayani, A., Rifai, A., \& Rohadi, T. (2018). Exploring Students' Response to Peer Feedback Strategy INEFL Writing Class at State Senior High School 1 Susukan. ELT Echo: The Journal of English Language Teaching in Foreign Language Context, 3(1), 59. doi: 10.24235/eltecho.v3i1.2810.

Rodliyah, R. S., Cahyono, B. Y., Widiati, U., \& Prayogo, J. A. (2017). The Effect of Meaningfocused Feedback as well as Language-focused Feedback in Journal Writing on Indonesian EFL Students' Writing Ability. International Journal of English and Education, 6(4), 103-113.

Saito, H., \& Fujita, T. (2004). Characteristics and user acceptance of peer rating in EFL writing classrooms. Language Teaching Research, 8(1), 31-54. doi: 10.1191/1362168804lr133oa.

Saville-Troike, M. (2006). Introducing Second Language Acquisition. Cambridge: Cambridge University Press. 
Putri Lasminiar, Implementation of Teacher and Peer Writing in Writing Hortatory ...

Sheen, Y., Wright, D., \& Moldawa, A. (2009). Differential Effects of Focused and Unfocused Written Correction on the Accurate Use of Grammatical Forms by Adult ESL learners. System, 37(4), 556-569. doi: 10.1016/j.system.2009.09.002.

Soles, D. (2007). The Concise Guide to Teaching Composition. New Jersey: Pearson/Prentice Hall.

Tai, H.-C., Lin, W.-C., \& Yang, S. C. (2015). Exploring the Effects of Peer Review and Teachers' Corrective Feedback on EFL Students' Online Writing Performance. Journal of Educational Computing Research, 53(2), 284-309. doi: 10.1177/0735633115597490.

Ting, M., \& Qian, Y. (2010). A Case Study of Peer Feedback in a Chinese EFL Writing Classroom. Chinese Journal of Applied Linguistics, 33(4), 87-98. doi: http://www.celea.org.cn/teic/92/10120606.pdf.

Widiastuti, I. A. M. S., Mukminatien, N., Prayogo, J. A., \& Irawati, E. (2019). Students' Perception of Assessment and Feedback Practices: Making Learning Visible. International Journal of Sustainability, Education, and Global Creative Economic (IJSEGCE), 2(1), 1-8. doi: 10.1234/ijsegce.v2i1.49.

Xiao, Y., \& Lucking, R. (2008). The Impact of Two Types of Peer Assessment on Students' Performance and Satisfaction within a Wiki Environment. The Internet and Higher Education, 11(3), 186-193. doi: 10.1016/j.iheduc.2008.06.005.

Yang, M., Badger, R., \& Yu, Z. (2006). A comparative study of peer and teacher feedback in a Chinese EFL writing class. Journal of Second Language Writing, 15(3), 179-200. doi: 10.1016/j.jslw.2006.09.004. 